A N N A L E S

UNIVER S T ATIS M A R A E C URIE-SKŁODOW K A

LUBLIN - POLONIA

VOL. XXXIII, 1

SECTIO J

2020

Uniwersytet Łódzki. Wydział Nauk o Wychowaniu

\title{
IZABELA KAMIŃSKA-JATCZAK
}

ORCID: 0000-0001-9556-0470

iza.kaminska8@gmail.com

\section{Aktywności ukierunkowane na odczucia rodzin w pracy socjalnej asystentów rodziny}

Activities Oriented Towards Sentiments of Families in the Social Work of Family Assistants

Propozycja Cytowania: Kamińska-Jatczak, I. (2020). Aktywności ukierunkowane na odczucia rodzin w pracy socjalnej asystentów rodziny. Annales Universitatis Mariae Curie-Skłodowska. Sectio J, Paedagogia-Psychologia, 33(1), 103-118. DOI: http://dx.doi.org/10.17951/j.2020.33.1.103-118.

\section{STRESZCZENIE}

Artykuł przedstawia analizę aktywności asystentów rodziny ukierunkowanych na odczucia rodzin. Są to linie aktywności mieszczące się w obrębie „pracy nad odczuciami”, po raz pierwszy opisanej w koncepcji społecznej organizacji pracy. Opracowanie stanowi fragment badań narracyjnych przeprowadzonych z asystentami rodziny w latach 2011-2017, których celem było poszukiwanie aktywności podmiotowych, poprzez które wyraża się tożsamość podmiotu działającego. W ramach badań powstała praca doktorska pt. Tożsamość profesjonalna $w$ narracjach asystentów rodziny. $\mathrm{W}$ artykule zaprezentowano wnioski związane $\mathrm{z}$ fragmentem przeprowadzonych badań, dotyczące przebiegu aktywności asystentów oddziałujących na emocje, uczucia oraz przekonania członków rodzin, które zmagają się z wieloma problemami życiowymi, co wpływa na ich wydolność opiekuńczo-wychowawczą. Artykuł może być inspiracją do namysłu nad sobą dla praktyków pracy socjalnej, którym zależy na profesjonalnym uwrażliwieniu na Drugiego oraz na jakości współtworzonych relacji pomocowych sprzyjających procesowi wsparcia.

Slowa kluczowe: aktywności ukierunkowane na odczucia rodzin; praca nad odczuciami; linie aktywności; praca socjalna asystentów rodziny

\section{WPROWADZENIE}

Pracę socjalną można postrzegać jako typ praktyki oddziaływania na Drugiego, który doświadcza sytuacji trudnej (homo absusus) (Marynowicz-Hetka, 
2006, s. 395), realizuje aktywności destrukcyjne dla siebie samego i innych, ma zachwiane poczucie kontroli nad własnym życiem, wreszcie jest nieufny i przyzwyczajony do reakcji stygmatyzujących. $Z$ tej perspektywy - w polu działania, jakim jest praca socjalna - szczególnie istotne stają się wszelkie przejawy aktywności, których celem jest upodmiotowianie, potwierdzanie cudzej wartości oraz przywracanie równowagi emocjonalnej. W niniejszym opracowaniu właśnie takie aktywności są przedmiotem analizy, a zostały omówione na przykładzie pola działania asystentów rodziny ${ }^{1}$.

Ze względu na istnienie pracy nad odczuciami już na najbardziej podstawowym poziomie aktywności oddziaływania na Drugiego (jak np. drobne gesty, spojrzenia, intonacja głosu itd.) podmiot działający nie zawsze uświadamia sobie jej obecność w swoim działaniu. Innymi słowy, aktywności ukierunkowane na odczucia, mimo że są realizowane w ramach pracy socjalnej, często pozostają niewidzialne lub są nie w pełni widzialne dla podmiotów działających w tym sensie, że z uwagi na swoją oczywistość stają się dla nich milcząco obecne, przezroczyste, bezrefleksyjne (Witkowski, 2014, s. 116). Z drugiej strony dla zwolenników uprawiania pracy socjalnej zgodnej z modelem relacyjnym (Marynowicz-Hetka, 2006, s. 393-396) namysł analityczny nad takimi aktywnościami warunkującymi jakość konstruowanych relacji z osobami wspieranymi stanowi niezbędną aktywność na drodze do kształtowania uwrażliwienia profesjonalnego $^{2}$ na tym polu. Celem niniejszego artykułu jest zarówno omówienie aktywności asystentów oddziałujących na odczucia Drugiego, jak i pobudzenie namysłu nad tymi aktywnościami.

\section{ROZUMIENIE PRACY NAD ODCZUCIAMI}

Artykuł przedstawia próbę uchwycenia złożoności codziennych aktywności asystentów rodziny, określanych jako aktywności ukierunkowane na odczucia ro-

1 Asystenci rodziny wspierają rodziny uznane przez przedstawicieli systemu pomocy społecznej za „doświadczające trudności w pełnieniu funkcji opiekuńczo-wychowawczych” (Ustawa z dnia 9 czerwca 2011 r. o wspieraniu rodziny i systemie pieczy zastępczej, Dz.U. 2011, nr 149, poz. 887, art. 2 ust. 1). Członkowie rodzin, na których oddziałują asystenci, to często rodzice pod nadzorem kuratora rodzinnego, którzy mają ograniczone prawa rodzicielskie, a także rodzice starający się o powrót dzieci, które zostały tymczasowo umieszczone poza rodziną, w instytucjach opieki zastępczej (Ustawa z dnia 9 czerwca 2011 r., art. 10 ust. 4.) Asystenci realizują pracę socjalną z rodzinami wieloproblemowymi. Nie zajmują się przeprowadzaniem wywiadów środowiskowych i przydzielaniem wsparcia finansowego - to zadania pracowników socjalnych.

2 Ze społeczno-pedagogicznego punktu widzenia rozwój profesjonalny związany jest z nabywaniem kompetencji zdawania sobie sprawy z podejmowanej aktywności oraz z uczestnictwa (również mentalnego) w tym procesie. Praktyk uwrażliwiony profesjonalnie pojmuje sens i znaczenie aktywności innych oraz sens i znaczenie własnych oddziaływań (Marynowicz-Hetka, 2006, s. 474). 
dzin. Opisywane aktywności asystentów mieszczą się w obrębie „pracy nad odczuciami" (sentimental work) (Strauss, Fagerhaugh, Suczek, Wiener, 2012, 2014). Z perspektywy koncepcji społecznej organizacji pracy stanowi ona typ działania (interakcyjny wymiar pracy) związany z wywieraniem wpływu na odczucia podmiotu naszego oddziaływania (Strauss i in., 2012, 2014). Ów koncept stał się inspiracją do namysłu nad aktywnościami asystentów rodziny, które oddziałują na odczucia członków rodzin związane z przeżywanymi emocjami, uczuciami oraz kształtowanymi przez nich przekonaniami. Innymi słowy, „praca nad odczuciami” opisana w ramach koncepcji społecznej organizacji pracy (Strauss i in., 2012, 2014) została potraktowana jako narzędzie inspirujące do analizy aktywności asystentów rodziny, służące do rekonstrukcji ich aktywności ukierunkowanych na odczucia rodzin, na które oddziałują.

Przyjęte w tym opracowaniu rozumienie terminu ,praca nad odczuciami” nieco odbiega od ujęcia Anselma Straussa (Strauss i in., 2012, 2014). Należy zwrócić uwagę na to, że problematyka pracy nad odczuciami wyłoniła się w innym kontekście społecznym niż przywoływana tu praca socjalna asystentów rodziny. Ów pierwotny kontekst budowania omawianego konceptu był związany z analizą aktywności personelu medycznego na terenie szpitali w Bay Area w San Francisco (Strauss i in., 2014, s. xiii). Z perspektywy Straussowskiej praca nad odczuciami stanowiła element każdego rodzaju pracy podejmowanej w stosunku do pacjentów chorych chronicznie i dotyczyła zarówno towarzyszenia pacjentom w radzeniu sobie z konsekwencjami emocjonalnymi choroby chronicznej - „niepokojem, lękiem, paniką, przygnębieniem" (Strauss i in., 2012, s. 801), jak i wspierania pacjentów podczas przeprowadzanych zabiegów medycznych, mogących wywołać „strach, zranienie wrażliwości, zagrożenie poczucia własnej wartości” (Strauss i in., 2012, s. 801).

Odmienny kontekst społeczny dotyczący pracy socjalnej z rodzinami problemowymi, do którego odnosi się przyjęte w artykule rozumienie pracy nad odczuciami, sprawił, że aktywności tu opisywane nie stanowią dokładnego odpowiednika „typów pracy nad odczuciami”, o których pisze Strauss (Strauss i in., 2012, s. 805-813) ${ }^{3}$. Opisywane aktywności asystentów są raczej próbą ukazania różno-

3 Strauss i jego współpracownicy wyodrębnili następujące typy pracy nad odczuciami: 1) „praca nad interakcjami i zasadami moralnymi” (interactional work and moral rules) - polega na przestrzeganiu określonych zasad czy też norm leżących u podstaw interakcji, które pozwalają określić danego człowieka jako uprzejmego, liczącego się z innymi, rozsądnego, sympatycznego. Taka aktywność ujawnia się w mikrozdarzeniach sytuacyjnych, związanych np. z ostrzeżeniem pacjenta o mającym nadejść krótkotrwałym bólu podczas zabiegu (Strauss i in., 2012, s. 805). Ten typ pracy może polegać na przygotowywaniu, ukierunkowywaniu pacjenta na to, co go czeka, jaki rodzaj leczenia zostanie wobec niego zastosowany, wyjaśnianiu co się z pacjentem dzieje i dlaczego odczuwa takie, a nie inne dolegliwości, a także na ustalaniu tempa realizowania zabiegu medycznego tak, by było ono dostosowane do możliwości znoszenia bólu przez pacjenta oraz rozkładu jego - często 
rodności i specyfiki możliwych typów pracy nad odczuciami, które zależą od ich usytuowania kontekstowego, m.in. odmienności relacji społecznych oraz problemów, wokół których oscyluje aktywność oddziaływania na Drugiego. W tekście rozważana jest więc praca nad odczuciami związana $\mathrm{z}$ towarzyszeniem członkom rodziny w ich zmaganiach z trudnościami życia codziennego. Są to osoby, które przeżywają wielorakie trudności związane z funkcjonowaniem społecznym, a ich wydolność opiekuńczo-wychowawcza z perspektywy sytemu pomocy społecznej wymaga wsparcia.

\section{OPIS BADAŃ}

Wnioski zawarte $\mathrm{w}$ artykule zostały oparte na fragmencie badań narracyjnych przeprowadzonych z asystentami rodziny, którzy identyfikowali podejmowane przez siebie aktywności w toku wywiadów narracyjnych ${ }^{4}$. Opracowanie zawiera wnioski dotyczące badań, których przedmiotem była nienormatywnie ujmowana tożsamość profesjonalna, rozumiana jako tożsamość podmiotu działającego, która zakłada nieustanną zależność tożsamości od aktywności (Kamiń-

ograniczonych - zasobów energii (Strauss i in., 2012, s. 806-807); 2) „praca nad zaufaniem” (trust work) - jest związana z okazywaniem respektu dla fizycznej, interakcyjnej, osobistej wrażliwości drugiej osoby. Złożona jest z rozmów, demonstracji kompetencji, łagodnych gestów i innych czynności służących zbudowaniu zaufania. Chodzi w niej również o przestrzeganie niepisanych lub jawnych umów z pacjentem (np. dotyczących zasad „zrobić to tak szybko i tak bezboleśnie, jak tylko się da”) lub o poinformowanie pacjenta o tym, że umiera (Strauss i in., 2012, s. 808); 3) ,praca nad zachowaniem spokoju" (composure work) - jest niezbędna w przeprowadzeniu pacjenta przez bolesne i przerażające zabiegi. Tego rodzaju praca polega na zabawianiu, dodawaniu otuchy oraz na pokrzepiających gestach (Strauss i in., 2012, s. 809); 4), „praca biograficzna” (biographical work) - opiera się na poznaniu biografii pacjenta tak, aby dowiedzieć się czegoś więcej o jego medycznej, społecznej historii, trybie życia, stosunkach z najbliższą rodziną, przyjaciółmi. Są to ważne informacje dla wyznaczenia odpowiedniej terapii (Strauss i in., 2012, s. 810); 5) „praca nad tożsamością” (identity work) - dotyczy oddziaływania na poczucie tożsamości w obliczu przedłużającej się i trudnej choroby (Strauss i in., 2012, s. 810). Chodzi o podejmowanie aktywności zmierzających do zmotywowania pacjenta, aby zmierzył się z życiem po opuszczeniu szpitala oraz by stawił czoła „nowej” rzeczywistości. Jest to niewątpliwie psychologiczny wymiar pracy z pacjentem, w którym pomaga się mu odzyskać równowagę emocjonalną czy satysfakcję z życia lub pomaga się mu pożegnać się z życiem (Strauss i in., 2012, s. 811); 6), ,praca nad kontekstami świadomości” (awareness context work) - również służy ochronie i podtrzymaniu tożsamości pacjenta. Poza tym pozwala zachować mu spokój (Strauss i in., 2012, s. 811). Polega na ukrywaniu informacji trudnych dla pacjenta, aby mógł się z nimi uporać (Strauss i in., 2012, s. 812); 7), „praca naprawcza” (rectification work), nazywana również „oczyszczającą” (Konecki, 2015, s. 28) - polega na „naprawianiu” interakcji między pacjentem a członkiem personelu, którego zachowanie było obraźliwe dla pacjenta. Taka aktywność może być realizowana np. przez pielęgniarkę wobec pacjenta, którego uraził lekarz (Strauss i in,, 2012, s. 812-813).

4 Na podstawie przeprowadzonych badań w latach 2011-2017 powstała praca doktorska pt. Tożsamość profesjonalna w narracjach asystentów rodziny (Kamińska-Jatczak, 2017b). 
ska-Jatczak, 2019). Celem badań było poszukiwanie aktywności podmiotowych, poprzez które wyraża się tożsamość podmiotu działającego. Pytania badawcze koncentrowały się na poszukiwaniu swoistych, regularnych wyrazów aktywności, które stają się podstawą do utożsamienia działającego jako podmiot sui generis. W toku badań analizowane były reprezentacje asystentów na temat różnego typu aktywności ukierunkowanych, w tym na odczucia Drugiego 5 .

Inspiracją do podjęcia badań było trzyletnie doświadczenie praktyczne autorki (2009-2011) zdobyte w pracy w charakterze asystenta rodziny. Był to czas, kiedy w Polsce dopiero kształtował się zawód asystenta rodziny ${ }^{6}$. Materiał badawczy, zawierający 13 wywiadów narracyjnych, został zgromadzony w okresie od listopada 2011 r. do marca 2013 r. Był to okres przełomowy dla kształtowania się asystentury rodzinnej w Polsce, ponieważ wówczas wypracowywano praktykę stosowania przepisów ustawowych?

Wywiady zostały zebrane zgodnie z procedurą wskazaną przez Fritza Schütze (1977), następnie poddano je szczegółowej transkrypcji. Część rejestrowana każdego wywiadu rozpoczynała się od zachęty wywołującej opowieść: Opowiedz mi o swojej pracy asystenta rodziny. Tego rodzaju sformułowanie wydawało się odpowiednie ze względu na duży stopień ogólności, a także neutralny charakter. Było ono poprzedzone stymulacją do narracji w formie instrukcji przedstawianej swoimi słowami przez badaczkę przed rozpoczęciem każdego wywiadu: Zależy mi na tym, byś opowiedziat(a) mi o swoich doświadczeniach zwiąanych z praca asystenta rodziny. Interesuje mnie wszystko, co dotyczy twojej pracy. Chciałabym, abyś to ty zadecydowat(a) o tym, w jaki sposób opowiesz o sobie $i$ swojej pracy. Zależy mi na tym, by zrozumieć ciebie i twoje doświadczenia. Badaczkę interesowała zatem biografia cząstkowa, zawężona do życia zawodowego narratorów.

Asystenci w narracjach ujawniali reprezentacje swoich aktywności, a tym samym wskazywali na to, co i jak czynią jako podmioty działające w polu oddziaływania na Drugiego (por. Barbier, 2016, s. 195). Badanie narracji asystentów było skoncentrowane na pojmowalności aktywności asystentów, a więc na uzyskaniu rozumiejącego wglądu w ich istotę i przebieg (por. Barbier, 2016, s. 151-153). Analiza polegała na interpretacji analitycznej wywiadów, zebranych

5 Tekst nie obejmuje wniosków związanych z innymi aktywnościami, ukierunkowanymi na konstruowanie lub przepływ informacji, dbałość o odczucia własne, konstruowanie reguł i zasad wzajemnego kontaktu, autoidentyfikację.

${ }^{6}$ W latach 2005-2011 asystenci byli zatrudniani w ramach projektów systemowych współfinansowanych z Europejskiego Funduszu Społecznego, miejskich programów finansowanych z budżetu miasta, projektów finansowanych przez Ministerstwo Pracy i Polityki Społecznej, działań międzyresortowych (por. Krasiejko, 2010, s. 100).

7 W 2012 r. weszła w życie ustawa z dnia 9 czerwca 2011 r. o wspieraniu rodziny i systemie pieczy zastępczej, która wprowadziła zawód asystenta rodziny do struktur polskiej pomocy społecznej. 
głównie przy pomocy procedury kodowania zaczerpniętej z teorii ugruntowanej (Charmaz, 2009).

Przedstawiona w opracowaniu interpretacja znaczeń, jakie asystenci nadawali swoim aktywnościom, stanowi analizę rzeczywistej praktyki zawodowej asystentów i nie jest dyskusją o tym, co być powinno, lecz raczej próbą ukazania tego, jak jest - na czym polega aktywność oddziaływania na odczucia Drugiego z perspektywy asystentów (por. Urbaniak-Zając, 2016, s. 43).

\section{LINIE AKTYWNOŚCI UKIERUNKOWANE NA ODCZUCIA RODZIN}

Asystenci rodziny realizują wiele złożonych linii aktywności, składających się z szeregu pojedynczych zdarzeń i czynności, które łączy wspólny cel, a mianowicie dbałość o odczucia ${ }^{8}$ członków rodziny. Linie aktywności różnią się kontekstem społecznym, w jakim występowały, przy czym ów kontekst jest rozumiany jako konstrukt społeczny (por. Scheff, 1990, s. 199) złożony ze specyficznych uwarunkowań sytuacyjnych oraz z zakresu świadomości asystentów dotyczącej określania możliwości podejmowania samodzielnej aktywności przez członków rodziny. Ponadto odróżniają się one od siebie swoim celem - oddziałują na emocje rodzące się w danych momentach aktywności lub są skierowane na bardziej trwałe odczucia podmiotu związane z jego uczuciami czy też przekonaniami. Linie aktywności pełnią też odmienną funkcję w procesie aktywności oddziaływania na rodzinę, którą starano się uchwycić poprzez odczytywanie znaczeń zawartych w narracjach asystentów dotyczących tego, na czym polega dana aktywność, co stanowi jej istotę. Analizowane linie aktywności były zróżnicowane także pod względem sposobów, przy pomocy których asystenci oddziałują na odczucia członków rodzin. Jest to szczególnie widoczne, gdy istnieje możliwość dokonywania analiz porównawczych dotyczących realizowania określonej linii aktywności przez inne podmioty działające - poszczególnych asystentów rodziny.

W kolejnych partiach artykułu zaprezentowano przykłady linii aktywności, o których opowiedzieli asystenci w swoich narracjach. Z tego względu tekst jedynie sygnalizuje, a nie wyczerpuje interpretację możliwych typów linii aktywności ukierunkowanych na odczucia w polu praktyki, jakim jest praca socjalna z rodzinami wieloproblemowymi. Do zaproponowanej typologii należy podchodzić w sposób elastyczny, ze świadomością, że możliwa jest dowolna konfiguracja omówionych linii aktywności w ramach jednostkowego działania, a także mając na uwadze dynamiczną i zmienną naturę rozwijających się aktywności w trakcie ich trwania (Kamińska-Jatczak, 2017a, s. 146).

8 Tematyka artykułu nie dotyczy tylko emocji pojawiających się w trakcie toczących się interakcji hic et nunc, lecz także uczuć i przekonań członków rodzin, co można określić zbiorczym terminem „odczucia” (por. Strauss i in., 2012, 2014). 


\section{Lagodzenie emocji}

Jest to linia aktywności uruchamiana w różnorakich sytuacjach stresujących dla członków rodziny, które wywołują w nich intensywne, często negatywne emocje. Asystenci podali przykłady dwóch rodzajów takich sytuacji: (1) kiedy łagodzenie emocji łączy się z przekazywaniem złych wiadomości oraz (2) gdy jest związane z realizowaniem trudnych spraw (jak np. sprawy urzędowe).

Najwięcej w swoich narracjach asystenci mówili o łagodzeniu emocji w ramach ich wizyt $w$ rodzinach mających miejsce bezpośrednio po nieoczekiwanym zdarzeniu umieszczenia dziecka w instytucji opieki zastępczej ${ }^{9}$. Asystent często jest pierwszą osobą, która informuje rodzinę o zaistniałej sytuacji - staje się wtedy posłańcem hiobowych wieści. W chwili kiedy rodzic dowiaduje się o odebraniu dziecka, często przeżywa on szok psychiczny, czemu towarzyszą silne emocje wyrażane przez intensywną ekspresję ${ }^{10}$. Niekiedy są to emocje negatywne skierowane w stronę asystenta, takie jak złość, gniew, wściekłość, co może łączyć się z obarczaniem go winą za zaistniałą sytuację. Przekazywanie rodzinie informacji o umieszczeniu dziecka w instytucji opieki zastępczej jest zatem sytuacją trudną emocjonalnie zarówno dla rodziny, jak i dla asystenta. W takich sytuacjach asystent jest tą osobą, która wkracza w przestrzeń silnych emocji, co obrazuje następujący fragment narracji: ona tam wszystkie stadia histerii przeszła.

Łagodzenie emocji związane z przekazywaniem złych wiadomości jest aktywnością polegającą na wsparciu emocjonalnym realizowanym poprzez umiejętne przekazywanie trudnych dla członków rodziny informacji, aby wywrzeć określony wpływ na proces przeżywania przez nich emocji. Taka aktywność polega na przekazywaniu interpretacji sytuacji, w jakiej znaleźli się rodzice dziecka, w sposób, który doda im otuchy i załagodzi ich wzburzone emocje. Znaczenie tej linii aktywności można thumaczyć przez pryzmat założeń Herberta Blumera, który zwracał uwagę na to, iż sposób, w jaki jednostka doświadcza wpływu niezależnych czynników zewnętrznych, jest zapośredniczony przez procesy interpretacji i definiowania, które mają charakter twórczy, kreatywny, przebiegający na swych własnych prawach (Blumer, 1969, s. 135). Asystent może wspierać rodzinę emocjonalnie poprzez przekazywanie jej definicji sytuacji, w jakiej się znalazła w taki sposób, by doprowadzić do emocjonalnej ulgi i obniżenia napięcia emocjonalnego. Patrząc na łagodzenie emocji z tej perspektywy, można interpretować tę aktywność jako próbę

9 Chodzi o tryb formalny regulujący postępowanie sądu, nazywany przez asystentów rodziny, pracowników socjalnych i kuratorów rodzinnych „natychmiastówką”, oznaczający natychmiastowe postępowanie prawno-administracyjne dotyczące tymczasowego umieszczenia dziecka poza rodziną biologiczną.

10 Ekspresja emocji to „wszelkie sygnały (zmiany w wyglądzie organizmu, ruchy i dźwięki) emitowane przez jednostkę, będące dla kogoś innego wskazówką przeżywania przez tę osobę określonej emocji” (Pawłowska, Chomczyński, 2012, s. 146). 
wpłynięcia na sposób doświadczania momentu krytycznego dla członków rodziny.

Asystenci na różne sposoby radzą sobie $\mathrm{z}$ intensywnymi emocjami pojawiającymi się podczas omawianej aktywności. Nie wszyscy są w stanie utrzymać zdystansowaną ekspresję emocjonalną i regulować komunikowanie emocji $\mathrm{w}$ oparciu o profesjonalny dystans ${ }^{11}$. Asystenci w trakcie omawianej linii aktywności odmiennie wyrażają swoje współczucie: używają gestów zarezerwowanych dla sfery prywatnej (jak np. przytulenie, trzymanie za rękę itd.), niektórzy niekiedy reagują intensywną ekspresją emocji, jaką jest płacz.

\section{Aktywność naprawcza}

Asystenci funkcjonują w ramach szerszych sieci instytucjonalnych, złożonych z reprezentantów instytucji skoncentrowanych wokół obszaru pracy z daną rodziną. Zdarza się, że w niektórych sieciach dochodzi do zaburzeń interakcyjnych na linii członek rodziny - pracownik socjalny lub inny profesjonalista. Przedstawiciel sieci instytucjonalnej może wejść w konfrontacyjny kontakt z członkiem rodziny - nakrzyczeć, zagrozić odebraniem pomocy materialnej, oskarżyć o niewywiązywanie się z deklarowanych zobowiązań itd. Członek rodziny po przeprowadzonym na nim ataku interakcyjnym często dalej przeżywa emocje negatywne (np. stres, strach, złość, frustrację, lęk, obawę, smutek itd.), jakich doświadczył $\mathrm{w}$ trakcie powstałej interakcji ${ }^{12}$, oraz poszukuje sojusznika w poradzeniu sobie z zaistniałym konfliktem.

Asystenci w swoich narracjach opowiadali o aktywności naprawczej ${ }^{13}$, jaką zapoczątkowywali po tym, jak członek rodziny po przeprowadzonym na nim ataku interakcyjnym zwrócił się do nich o wsparcie ${ }^{14}$. Omawiana linia aktywności polega na przywracaniu spokoju członkowi rodziny (niech pani się nie unosi, niech pani sie nie denerwuje absolutnie - fragment narracji) oraz towarzyszeniu mu w bezpośrednich kontaktach z ,atakującym” przedstawicielem instytucji.

11 Profesjonalny dystans stanowi efekt pracy nad sobą, pozwala łączyć zaangażowanie emocjonalne z przytomną oceną i zarządzaniem sprawą (Granosik, 2002, s. 27).

12 Beata Pawłowska nazywa takie zjawisko „efektem świeżości”. Chodzi o to, że jest się „świeżo” pod wpływem doświadczonych emocji i wciąż się je przeżywa w wyniku „wdrukowania w pamięć stanu emocjonalnego" (Pawłowska, 2013, s. 144).

13 Strauss wyróżnił ,pracę naprawczą” (rectification work) jako jeden z typów pracy nad odczuciami (Strauss i in., 2012, s. 812-813). Czerpiąc inspirację z jego dorobku naukowego, posługuję się terminem ,aktywność naprawcza”, przy czym rozumiem go szerzej - nie tylko jako usuwanie negatywnych konsekwencji emocjonalnych u członków rodziny, którzy ucierpieli pod wpływem zaburzeń interakcyjnych, lecz także jako oddziaływanie na odbiór społeczny członków rodziny przez osoby, które dokonały ataku interakcyjnego skierowanego w ich stronę.

14 Oczywiście trzeba mieć na względzie również odwrotny wariant, kiedy asystent pomimo uzyskania wiedzy o przeprowadzonym ataku interakcyjnym na członka rodziny nie podejmuje czynności naprawczych (np. ze względu na przekonanie, że był to sprawiedliwy atak). 
Współtowarzyszenie członkowi rodziny w kolejnych spotkaniach z taką osobą jest elementem aktywności naprawczej, która służy przeciwdziałaniu zaburzeniu emocjonalnego bezpieczeństwa, do którego mogłoby dojść w sytuacji kolejnego konfrontacyjnego kontaktu skierowanego w jego stronę. Asystent, uczestnicząc wraz z członkiem rodziny w trudnych dla niego interakcjach, jednocześnie wspiera jego gotowość do kontynuowania toku załatwiania danej sprawy (np. dopełnienie formalności związanych z przyznaniem wsparcia materialnego).

Linia aktywności naprawczej może rozszerzyć się o walkę negocjacyjną asystenta $\mathrm{z}$ innymi przedstawicielami sieci instytucjonalnej na rzecz praw rodzin (np. prawo do przyznania świadczeń finansowych lub prawo do regularnych odwiedzin dzieci w instytucji opieki zastępczej). W takim wypadku asystent dodatkowo podejmuje wysiłek wywierania wpływu na odbiór społeczny członka rodziny przedstawia go w pozytywnym świetle, prezentuje odmienne stanowisko będące przeciwwagą dla utrwalającego się procesu negatywnej kategoryzacji oraz przypisywania mu negatywnych reprezentacji tożsamościowych.

Aktywność naprawcza zdaniem asystentów jest formą wsparcia emocjonalnego dla członków rodziny, które polega na dostrzeganiu i podtrzymywaniu ich starań wyjścia $\mathrm{z}$,życiowego bagna” ${ }^{15}$ poprzez podejmowanie funkcji ich sojusznika w zmaganiach z innymi przedstawicielami instytucji. Takie wsparcie może stanowić mobilizację do podejmowania dalszego wysiłku na drodze do przywracania równowagi życiowej - odzyskania dzieci umieszczonych w placówkach opieki zastępczej, rozpoczęcia trzeźwej biografii itd.

\section{Chwalenie}

Aby wzmocnić w członkach rodziny poczucie własnej wartości i sprawstwa, asystenci często chwalą ich postępy. Może się to odbywać na zasadzie dostrzegania i komplementowania każdego, nawet najdrobniejszego przejawu aktywności, którą asystent uzna za konstruktywną.

Mariusz Granosik (2006, s. 142) wskazuje, że zabiegi służące podnoszeniu samooceny „klienta” są stałym elementem pracy nad jego tożsamością. Ten aspekt komplementowania uwidacznia się w narracji, w której asystentka postrzega chwalenie - głaskanie, techtanie (fragment narracji) jako sposób budowania wiary w siebie u członków rodziny. Asystentka poprzez chwalenie stara się przywrócić członkom rodziny wiarę w ich możliwości sprawcze czyniące ich zdolnymi do podejmowania samodzielnej aktywności.

15 Metafora bagna, użyta przez jedną z asystentek, wydaje się trafna, ponieważ oddaje specyfikę sytuacji życiowej rodzin wieloproblemowych - niekiedy wysiłki, jakie podejmują członkowie tych rodzin, aby coś zmienić, przypominają wydostawanie się z bagna, w którym ma się spowolnione ruchy, przez co mogą być one niezauważalne lub prowadzić do jeszcze większego zanurzenia. 
Izabela Krasiejko wymienia „komplementowanie” jako jedną z metod „pracy socjalno-terapeutycznej”, która służy „wydobyciu, wzmocnieniu, rozszerzeniu” sił członka rodziny, które mogą być użyteczne w osiągnięciu jego celów życiowych (Krasiejko, 2010, s. 251, 197). Należy jednak zauważyć, że uruchamianie czynności, z jakich składa się chwalenie, nie jest równoznaczne z konstrukcjami mentalnymi, jakie asystent tworzy na temat tej linii aktywności. Jedni asystenci mogą przyporządkowywać takiej aktywności „reprezentacje finalizujące”"16, które wpisują się w celowość, jaką np. opisuje I. Krasiejko, lecz inni mogą po prostu spontanicznie reagować na dynamikę obserwowanych sytuacji zachodzących $\mathrm{w}$ interakcjach czy też na komunikaty pojawiające się w toku rozmowy z rodziną.

\section{Mobilizowanie do przelamywania barier emocjonalnych}

Zdaniem Jeana-Marie Barbiera (2016, s. 46) istnieje „instynkt aktywności”, który łączy się z ,instynktem ochrony siebie poprzez podejmowanie aktywności”. Asystenci spotykają osoby, których ,instynkt aktywności” został zablokowany, utknął w martwym punkcie, czego konsekwencją jest ograniczenie bądź zanik widocznej aktywności oraz destrukcyjna aktywność mentalna, której towarzyszą trudne emocje, takie jak np. wstyd, lęk, niepokój, mogące przekształcić się w trwalsze uczucie bezsilności, bezradności, bezsensu. W kontaktach z takimi osobami asystenci starają się na różne sposoby mobilizować je do przełamywania barier emocjonalnych uniemożliwiających im zrealizowanie wielu zadań z życia codziennego. Istotą tej linii aktywności jest więc pobudzanie członków rodziny do pokonywania emocji przeszkadzających im w konstruktywnej aktywności oraz wywieranie wpływu na ich przekonania dotyczące zdolności zrealizowania określonego zadania.

Niektórzy asystenci mobilizują członków rodziny do podjęcia określonej aktywności poprzez perswadowanie polegające na przekonywaniu przy użyciu zachęt do podjęcia wyzwania: dużo rzeczy można zalatwić, no tylko trzeba wyjść $z$ domu i nie wstydzić się (fragment narracji). Stosują przy tym tzw. pomyślną wróżbę jako pozytywny argument perswazyjny: kiedy mnie pan/pani posłucha, wszystko dobrze się ułoży (Krasiejko, 2012, s. 164). Innym sposobem realizowania tej linii aktywności jest stworzenie presji sytuacyjnej uniemożliwiającej członkowi rodziny odłożenie spraw na później: ja mówię - nie, królowo, wstajemy, idziemy (fragment narracji). Trzecim sposobem, za pomocą którego asystenci mobilizowali członków rodziny do przełamywania barier emocjonalnych, było oswajanie ich z sytuacją stresującą, polegające na towarzyszeniu im podczas realizowania zadań w różnego typu instytucjach: więc ja z nim idę, on załatwia

16 Reprezentacje finalizujące dotyczą tego, co podmiot działający uznaje za pożądane dla niego samego, dla jego aktywności i otoczenia (Barbier, 2016, s. 196). 
sprawy, ale zawsze ja go tak uspokajam i wyciszam (fragment narracji). Obecność asystenta w sytuacjach społecznych stanowiących wyzwanie dla członków rodziny i budzących trudne emocje może służyć oswajaniu tych emocji i stanowić mobilizację do ich przezwyciężenia.

\section{Budowanie zaufania}

Jak zauważyło wielu asystentów, zaufanie ze strony rodziny jest kapitałem, który kumuluje się z biegiem czasu. Anselm Strauss podkreśla złożoność linii aktywności, jaką jest zdobywanie zaufania: „(...) zdobycie czyjegoś zaufania może być zadaniem bardzo złożonym, wymagającym mnóstwa czasu, wielu rozmów, demonstracji kompetencji, wielu łagodnych gestów i tym podobnych [rzeczy I.K.J.]" (Strauss i in., 2012, s. 808).

Zdobycie zaufania jest niezbędne do tego, by członkowie rodziny zaczęli się otwierać przed asystentem, czyli wykazywać aktywności sprzyjające relacji pomocowej, takie jak: zwierzanie się ze swoich problemów życiowych, proszenie o pomoc, snucie szczerej, niezafałszowanej narracji. Zbudowanie zaufania w kontaktach z rodziną jest trzonem, na którym bazuje aktywność asystenta oparta o szczere, niezafałszowane relacje.

Linia aktywności, jaką jest budowanie zaufania, polega na przekazywaniu przez asystentów pozytywnych obrazów siebie i wywieraniu wpływu na przypisywane im reprezentacje tożsamościowe przez członków rodziny. Przebieg tej linii aktywności może przybierać różną dynamikę w zależności od stopnia otwartości rodziny na kontakt $\mathrm{z}$ asystentem, kierunek aktywności asystenta (mniej lub bardziej sprzyjający pozyskiwaniu zaufania rodziny) oraz ocenę aktywności asystenta przez członków rodziny pod kątem kompatybilności z przypisywanymi mu reprezentacjami tożsamościowymi - osoby godnej lub niegodnej zaufania.

Asystenci niejednokrotnie spotykają się z nieufnością czy niechęcią ze strony rodzin, spowodowaną wcześniejszymi doświadczeniami zgromadzonymi w oparciu o kontakt z przedstawicielami sieci instytucjonalnej lub z innym asystentem. Przypisywanie a priori negatywnych reprezentacji tożsamościowych może być spowodowane również brakiem możliwości dokonania dobrowolnego wyboru. Jak wynika z narracji asystentów, niekiedy rodzice podejmują decyzję o współpracy $\mathrm{z}$ asystentem pod naciskiem pracowników socjalnych i kuratorów rodzinnych ${ }^{17}$. Stawianie rodzin w sytuacji przymusu powoduje konsekwencje w postaci traktowania wizyt asystentów jako uciążliwej ingerencji.

17 Z perspektywy ustawy z dnia 9 czerwca 2011 r. o wspieraniu rodziny i systemie pieczy zastępczej wsparcie asystenta powinno być dobrowolne (art. 8 ust. 3). Natomiast biorąc pod uwagę Kodeks rodzinny i opiekuńczy, istnieje możliwość zobowiązania sądowego rodziny do współpracy $\mathrm{z}$ asystentem w przypadku zagrożenia dobra dziecka (art. 109 ust. 2 pkt 1). 
Z drugiej strony asystent może zostać obdarzony przez członków rodziny dużym kredytem zaufania i stać się dla nich „innym ważnym”18 - kimś, kto jest oparciem, towarzyszem $w$ codziennej walce (fragment narracji). Sprostanie tak znaczącym oczekiwaniom może być odczuwane przez asystenta jako obciążające psychicznie, szczególnie gdy odczuwa on konflikt lojalności (fragment narracji) wynikający ze zmiany orientacji i kierunku aktywności oddziaływania na rodzinę. Dzieje się tak, kiedy np. asystent w toku pracy z daną rodziną weryfikuje wcześniej skonstruowaną kategoryzację - uznaje rodzinę za czasowo lub trwale niezdolną do wychowywania dzieci i informuje o tym innych uczestników sieci instytucjonalnej (np. przedstawicieli sądu rodzinnego). Podczas kontaktów asystenta z członkami rodziny może zatem dojść do zerwania relacji opartych na zaufaniu w wyniku podjęcia aktywności uznanej przez nich za przejaw nielojalności. Wynika to z dynamiki takich relacji, w których od obdarzonego zaufaniem oczekuje się, że okaże się on jego godny, a więc wiarygodny, lojalny (por. Czajkowska, 2010, s. 409).

Omawianą linię aktywności można rozpatrywać jako adaptacyjne dostosowywanie się asystenta i członków rodziny do pojawiających się przejawów interakcyjnych sygnalizujących budowanie lub zanik zaufania, na które reagują oni poprzez tworzenie określonych reprezentacji stanowiących interpretację tych przejawów, co przekłada się na podejmowanie dalszych czynności (por. Rompf, 2012, s. 237).

\section{Dbałość o odczucia}

W kontaktach z członkami rodziny na ogół asystenci starają się dbać o pozytywną atmosferę, jaka wytwarza się w ich toku. Sprzyja temu kształtowanie formatu kontaktu ${ }^{19}$, który Mariusz Granosik (2006, s. 29-31) określił jako format zbliżenia. Asystenci starają się unikać konfrontacyjnego sposobu komunikowania się, który mógłby spowodować wzrost napięcia emocjonalnego i poczucie konieczności obrony ze strony członka rodziny. Aby wytworzyć format zbliżenia, asystenci przekazują rodzinom pozytywne obrazy siebie, starają się uwzględniać emocje członków rodziny oraz antycypować prawdopodobieństwo ich zaburzenia.

Tego rodzaju linia aktywności jest wyraziście dostrzegalna m.in. w sytuacjach wywołujących zdenerwowanie u asystentów, spowodowane postępowaniem członków rodziny (jak np. brak realizacji zobowiązań wynikających ze wzajemnych ustaleń). Z dbałością o odczucia członka rodziny mamy do czynienia, kiedy asystent pomimo emocjonalnego wzburzenia stara się przekazać swoje niezadowolenie w sposób, który nie wywoła u drugiej osoby emocjonalnego dys-

18 Zdaniem Anity Gulczyńskiej (2013, s. 148) ,innym ważnym” jest osoba uznana za znaczącą z wyboru podmiotów uznających ją za ważną.

19 Chodzi o typ kontaktu oparty o określone zasady interakcyjne (Granosik, 2006, s. 28-31). 
komfortu (np. w postaci poczucia winy, bezwartościowości, dyskredytacji) lub nie spowoduje zaburzenia czy też przerwania kontaktu: nawet jak jestem zdenerwowana, że coś tam na przyktad nie jest załatwione (...) nie zrobione, to nie daje im do zrozumienia tego, że jakby ganię ich (fragment narracji). Innym przykładem realizowania tej linii aktywności przez asystenta jest okazywanie wyrozumiałości dla gorszego samopoczucia członka rodziny oraz odstąpienie od realizacji wcześniej zaplanowanych zadań bez robienia wyrzutów, wypominania czy innych konfrontacyjnych form kontaktu.

\section{Pobudzanie do namysłu nad sobą}

Rozmowy na temat doświadczeń biograficznych członków rodziny, dotyczące tego co przeżyli, co zdarzyło się w ich życiu, w niektórych narracjach asystentów opisywane są jako osobne linie aktywności, intencjonalnie ukierunkowane na pobudzanie członków rodziny do podjęcia namysłu nad sobą. Asystenci angażują członków rodziny w rozmowy o przeżywanych problemach, które niekiedy przekształcają się w historie o ich życiu. Pobudzanie do namysłu nad sobą nabiera szczególnego znaczenia po zdarzeniach przełomowych, stanowiących punkty zwrotne w życiu rodziny, jak np. zabranie dzieci i umieszczenie ich w placówce opieki zastępczej, podjęcie leczenia odwykowego itd.

Rozmowy ukierunkowane na pobudzanie u członków rodziny refleksji nad sobą pełnią dwie zasadnicze funkcje. Po pierwsze, służą wsparciu emocjonalnemu, jakiego asystent udziela podczas słuchania poprzez okazywanie swojej akceptacji. Po drugie, dają asystentowi dostęp do wiedzy własnej członków rodziny, stanowiącej wyraz świata przeżywanego, przez pryzmat którego nadają znaczenia swoim doświadczeniom życiowym (Kamińska, 2012).

Asystenci na różne sposoby realizują tę linię aktywności. Jedna z asystentek zadawała prace domowe (fragment narracji) polegające na formułowaniu pytań do przemyślenia w samotności. Poprzez zadawanie pytań starała się wyzwolić w członku rodziny autorefleksję nad sobą (np. nad historią jego uzależnienia i rodzicielstwa). Inna asystentka dzieliła się z członkami rodziny własnymi przemyśleniami na temat ich życia i prowadziła z nimi rozmowy w oparciu o przedstawioną interpretację ${ }^{20}$. Zdaniem asystentki takie rozmowy polegały na uświadamianiu tego, z czego dotad oni [członkowie rodziny - I.K.J.] nie zdawali sobie sprawy (fragment narracji).

20 Przemyślenia stanowiły konceptualizację doświadczeń życiowych członka rodziny, składającą się z: identyfikacji - określenia problemu i jego źródła; analizy - wskazania związków między poszczególnymi elementami (np. między nadużywaniem alkoholu w rodzinie pochodzenia a zdolnością wchodzenia w relacje ze sobą samym i z innymi); waloryzacji - określenia następstw, czyli wpływu, jaki dany problem wywiera na obecne funkcjonowanie rodziny; antycypacji - przedstawienia skutków, jakie może wywrzeć dany problem na przyszłe funkcjonowanie rodziny. 
Asystenci skłaniają członków rodziny do namysłu nad sobą, który może przerodzić się w ich realną pracę biograficzną, polegającą na interpretowaniu i redefiniowaniu własnych doświadczeń życiowych, co w rezultacie może przynieść zmianę ich dotychczasowej orientacji życiowej (por. Riemann, Schütze, 2012, s. 395).

Pozostaje jeszcze trudna do rozstrzygnięcia kwestia, na ile asystent powinien ingerować w proces namysłu nad sobą członków rodzin i przekazywać im własne interpretacje ich życiowych trudności. Narracje asystentek skłaniają do rozważań dotyczących wyzwań i ograniczeń, jakie niesie za sobą traktowanie użytkowników (service-users) jako ekspertów w zakresie własnych problemów.

\section{ZAKOŃCZENIE}

Celem artykułu była analiza aktywności określanych jako ukierunkowane na odczucia rodzin, podejmowanych w polu praktyki, jakim jest praca socjalna, przez asystentów rodziny. Intencją było ukazanie złożoności subtelnych i często niedostrzegalnych aktywności dotyczących Drugiego, rozumianego jako podmiot odczuwający (Marynowicz-Hetka, 2006, s. 241). Są to aktywności istotne w procesie budowania relacji pomocowej, które wywierają wpływ na jej specyfikę i przebieg, dlatego wymagają pogłębionego namysłu.

Złożoność wskazanych tu aktywności wykracza poza prezentowaną tematykę i wiąże się z istotą tych aktywności, które należałoby rozpatrywać jako wielo-aktywności czy też multi-aktywności (Barbier, 2016, s. 244). Podmiot działający, kiedy angażuje się w aktywności oddziaływania na odczucia Drugiego, jednocześnie podejmuje pracę nad własną sferą odczuć21. Możliwości/dyspozycje podmiotu działającego dotyczące sfery jego odczuć wiążą się z tym, w jaki sposób realizuje on linie aktywności ukierunkowane na odczucia innych. Aktywności te są ze sobą powiązane, co uwidacznia się również w tym, że kiedy podmiot profesjonalny podejmuje namysł nad tym, jak realizuje aktywności oddziałujące na odczucia określonych adresatów, jednocześnie podejmuje refleksję nad sobą jako „narzędziem” ich dokonywania. W tym zakresie niniejszy artykuł może być inspiracją dla asystentów rodziny oraz innych praktyków pracy socjalnej do namysłu nad ramami ich działania, które umiejscowione są w nich samych (por. Marynowicz-Hetka, 2006, s. 239), znajdujących się na drodze dojrzewania do działania profesjonalnego.

${ }^{21}$ Zamierzam poświęcić osobny tekst aktywnościom radzenia sobie z własnymi odczuciami przez asystentów rodziny. 


\section{BIBLIOGRAFIA}

Barbier, J.-M. (2016). Leksykon analizy aktywności. Konceptualizacje zwyczajowych pojęć. Łódź: Wydawnictwo UŁ.

Blumer, H. (1969). Symbolic Interactionism. Perspective and Method. Berkeley, Los Angeles, London: University of California Press.

Charmaz, K. (2009). Teoria ugruntowana. Praktyczny przewodnik po analizie jakościowej. Warszawa: Wydawnictwo Naukowe PWN.

Czajkowska, M. (2010). Zaufanie w organizacji - filozoficzny zarys podstaw zagadnienia. Acta Universitatis Lodziensis. Folia Oeconomica, 234, 409-420.

Granosik, M. (2002). Kształcenie - tożsamość - działanie. O biograficznym wymiarze pracy socjalnej. W: E. Marynowicz-Hetka (red.), Badanie - działanie - kształcenie, czyli o przydatności dyscyplin społecznych dla doskonalenia praktyki profesji społecznych $w$ dziedzinie oświaty, kultury i pracy socjalnej (s. 21-33). Łódź: Łódzkie Towarzystwo Naukowe.

Granosik, M. (2006). Profesjonalny wymiar pracy socjalnej. Katowice: Wydawnictwo Naukowe „Śląsk”.

Gulczyńska, A. (2013). ,, Chłopaki z dzielnicy”. Studium spoleczno-pedagogiczne z perspektywy interakcyjnej. Łódź: Wydawnictwo UŁ.

Kamińska, I. (2012). Knowledge of biographical experiences of the mentally ill and the quality of empowerment. Socialinis darbas: patirtis ir metodai, 9(1), 235-253.

Kamińska-Jatczak, I. (2017a). Linie aktywności w procesie przepływu informacji - przykład asystentów rodziny. W: A. Żukiewicz (red.), Pedagog społeczny. Teoria i praktyka działalności społecznej (s. 145-159). Łódź: Wydawnictwo UŁ.

Kamińska-Jatczak, I. (2017b). Tożsamość profesjonalna $w$ narracjach asystentów rodziny (Praca doktorska, mps). Pobrane z: http://dspace.uni.lodz.pl:8080/xmlui/handle/11089/23030 (dostęp: 24.01.2020).

Kamińska-Jatczak, I. (2019). Przejawy konstruowania tożsamości profesjonalnej podmiotu działającego. Przykład asystentów rodziny. Pedagogika Społeczna, 2(72), 183-202.

DOI: https://doi.org/10.35464/1642-672X.PS.2019.2.13

Konecki, K.T. (2015). Anselm L. Strauss - pragmatyczne korzenie, pragmatyczne konsekwencje. Przegląd Socjologii Jakościowej, 11(1), 12-39.

Krasiejko, I. (2010). Metodyka działania asystenta rodziny. Podejście skoncentrowane na rozwiąaniach w pracy socjalnej. Katowice: Wydawnictwo Naukowe „Śląsk”.

Krasiejko, I. (2012). Metodyka działania asystenta rodziny. Różne modele pracy socjalnej i terapeutycznej z rodzina. Katowice: Wydawnictwo Naukowe „Śląsk”.

Marynowicz- Hetka, E. (2006). Pedagogika społeczna. Podręcznik akademicki. Wykład (T. 1). Warszawa: Wydawnictwo Naukowe PWN.

Pawłowska, B. (2013). Czynniki wpływające na powstawanie i/lub ukrywanie emocji w pracy przedstawiciela handlowego i nauczyciela. Przeglą Socjologii Jakościowej, 9(2), 128-151.

Pawłowska, B., Chomczyński, P. (2012). Sposoby radzenia sobie z emocjami negatywnymi na przykładzie grupy nauczycieli. Studia Edukacyjne, 21, 141-162.

Riemann, G., Schütze, F. (2012). „Trajektoria” jako podstawowa koncepcja teoretyczna w analizach cierpienia i bezładnych procesów społecznych. W: K. Kaźmierska (red.), Metoda biograficzna w socjologii. Antologia tekstów (s. 389-414). Kraków: Zakład Wydawniczy Nomos.

Rompf, S.A. (2012). Trust and Rationality. An Integrative Framework for Trust Research. Mannheim: Springer VS.

Scheff, T. (1990). Microsociology. Discourse, Emotion and Social Structure. Chicago-London: Chicago University Press. 
Schütze, F. (1977). Die Technik des narrativen Interviews in Interaktionsfeldstudien - dargestellt an einem Projekt zur Erforschung von kommunalen Machtstrukturen. Bielefeld: Fakultät für Soziologie, Universität Bielefeld, 1, 1-62.

Strauss, A.L., Fagerhaugh, S., Suczek, B., Wiener, C. (2012). Praca nad odczuciami. W: K. Kaźmierska (red.), Metoda biograficzna w socjologii. Antologia tekstów (s. 801-824). Kraków: Zakład Wydawniczy Nomos.

Strauss, A.L., Fagerhaugh, S., Suczek, B., Wiener, C. (2014). Social Organization of Medical Work. London-Chicago: University of Chicago Press.

Urbaniak-Zając, D. (2016). W poszukiwaniu teorii działania profesjonalnego pedagogów. Badania rekonstrukcyjne. Kraków: Oficyna Wydawnicza Impuls.

Ustawa z dnia 25 lutego 1964 r. - Kodeks rodzinny i opiekuńczy (Dz.U. 2015, poz. 2082).

Ustawa z dnia 9 czerwca 2011 r. o wspieraniu rodziny i systemie pieczy zastępczej (Dz.U. 2011, nr 149, poz. 887).

Witkowski, L. (2014). Niewidzialne środowisko. Pedagogika kompletna Heleny Radlińskiej jako krytyczna ekologia idei, umystu $i$ wychowania. O miejscu pedagogiki w przełomie dwoistości w humanistyce. Kraków: Oficyna Wydawnicza Impuls.

\section{SUMMARY}

The article presents an analysis of the activities of child protection workers focused on the sentiments of families. These are lines of activities within the "sentimental work" described for the first time in the concept of social organisation of work. The study is a fragment of narrative research conducted with child protection workers in the years 2011-2017, the purpose of which was to search for subjective activities through which the identity of the acting entity is expressed. As part of the research, a doctoral thesis was created entitled Professional identity in narratives of family assistants. The article presents conclusions related to the activities of child protection workers which affecting the emotions, feelings and beliefs of family members who are struggling with many life problems, which affects their protective and educational efficiency. The article may be an inspiration for self-reflection for social work practitioners who care about professional sensitivity and the quality of co-created supporting relations.

Keywords: activities oriented towards sentiments of families; sentimental work; lines of activities; social work of child protection workers 